\title{
ANALISIS PENERIMAAN APLIKASI INDRIVER DENGAN MENGGUNAKAN PENDEKATAN MODIFIED TECHNOLOGY ACCEPTANCE MODEL
}

\section{Bonny Hendrawan, Tomi Hartanto dan Sendy Wulansari}

Universitas Budi Luhur Jakarta, Indonesia

Email: bonnyavolution@gmal.com, tomihartanto96@gmail.com dan sendy597@gmail.com

\section{Abstract}

This research is based on testing whether the price that can not be done, the card, the numbered reading power and usefulness are bernyimat and intention for the user of the system in the applicationdriver. The Indriver Application System Acceptance analysis uses the exemplary Technology Acceptance click model. The data is from user applications from 100 indrivers in South Jakarta with a cavalier online questionnaire. The data analysis was conducted using the Element-Partial Least Square (SEM-PLS) Compliant Model using SmartPLS3. The results of the 2020 price price and positive effects and energy on the use of indriver namedn. Easy pricing has a positive effect but not as low as indriver price. Plant-based power may have a positive and energizing effect on the user on the indriver. Its chewing uses are positive effects and energy on indriver users. The service room has a positive effect and speaks to its obvious uses. Room service services have a positive effect but not good on users in the year indriver. User promo users have a positive effect and very intent intention to driver on on. Located from the results of the study and above, it can be concluded that the price is positive and wide spread perception perception statistically.

Keywords: price flexibility; service quality; perceived ease of use; perceived usefulness; user saisfaction; and behavioral intention to use

\section{Abstrak}

Penelitian ini bertujuan untuk menguji apakah fleksibilitas harga, kualitas layanan, kemudahan penggunaan yang dirasakan dan kegunaan yang dirasakan mempengaruhi kepuasan pengguna dan niat untuk menggunakan sistem aplikasi inDriver. Analisis penerimaan sistem aplikasi InDriver menggunakan pendekatan Model Penerimaan teknologi yang dimodifikasi. Data tersebut diperoleh dari 100 pengguna aplikasi indriver di Jakarta Selatan dengan mendistribusikan kuesioner online. Analisis data dilakukan menggunakan model persamaan struktural Partial Least Square (SEM-PLS) menggunakan SmartPLS3. Hasil penelitian menunjukkan bahwa fleksibilitas harga memiliki efek positif dan signifikan pada kemudahan penggunaan inDriver yang dirasakan. Fleksibilitas harga memiliki efek positif tetapi tidak signifikan pada kepuasan pengguna inDriver. Kemudahan penggunaan yang dirasakan memiliki efek positif dan signifikan pada kepuasan pengguna inDriver. Kegunaan yang dirasakan memiliki efek positif dan signifikan pada kepuasan pengguna inDriver. Kualitas layanan memiliki efek positif dan signifikan 
pada kegunaan yang dirasakan. Kualitas layanan memiliki efek positif tetapi tidak signifikan pada kepuasan pengguna inDriver. Kepuasan pengguna memiliki efek positif dan signifikan pada niat perilaku untuk digunakan pada driver. Berdasarkan hasil penelitian dan pembahasan di atas, dapat disimpulkan bahwa fleksibilitas harga berpengaruh positif dan signifikan terhadap persepsi kemudahan secara statistik diterima.

Kata Kunci: fleksibilitas harga; kualitas layanan; kemudahan penggunaan yang dirasakan; kegunaan perceived; tindakan atisf pengguna; niat perilaku untuk andase

\section{Pendahuluan}

Inovasi teknologi berkembang dengan pesat hampir di semua sektor, tidak terkecuali pada sektor transportasi umum seperti ojek dan taksi. Bukti inovasi dalam bidang bisnis transportasi ojek dan taksi tersebut adalah dengan munculnya operator online ride-sharing dengan mentransformasi layanan ojek dan taksi secara online (Magfiroh, 2019). Hal ini juga sebagai bukti bahwa perintis bisnis (start up) di Indonesia mampu berinovasi dengan baik. Perubahan ini menjadi contoh bagaimana sistem sharing economy atau ekonomi berbagi berbasis teknologi telah muncul dan mewabah di masyarakat. Sistem sharing economy memungkinkan seseorang untuk meminjam ataupun menyewakan aset yang dimiliki, termasuk dalam hal ini meminjamkan tenaga dan kendaraan dalam wujud jasa online ride-sharing (Hastuti et al., 2020).

Fenomena munculnya jasa online ride-sharing mampu menciptakan lapanganlapangan kerja baru untuk masyarakat di kota besar seluruh dunia (Flores \& Rayle, 2017) ditambah dengan tawaran pendapatan yang menarik bagi yang berminat untuk menjadi mitra di dalamnya (Dong, Wang, Li, \& Zhang, 2018).

Tidak dapat dipungkiri bahwa munculnya jasa online ride-sharing memunculkan lapangan-lapangan kerja baru untuk masyarakat di kota besar seluruh dunia (Flores \& Rayle, 2017) ditambah dengan tawaran pendapatan yang menarik bagi yang berminat untuk menjadi mitra di dalamnya (Dong et al., 2018). Kemunculan operator transportasi online ride-sharing ini sukses untuk menarik berbagai kalangan, mulai tukang ojek pangkalan hingga pegawai swasta, untuk terlibat dalam bisnis ini. Jasa transportasi online ride-sharing sangat menolong bagi masyarakat, tidak hanya dari segi layanan yang memudahkan bagi pelanggan, melainkan juga karena jasa transportasi online ridesharing mampu membuka lapangan kerja baru bagi masyarakat yang membutuhkan

Kemunculan operator transportasi online ride-sharing ini sukses menarik perhatian mulai dari tukang ojek pangkalan hingga pegawai swasta terlibat dalam bisnis ini. Jasa transportasi online ride-sharing sangat membantu masyarakat tidak hanya dari segi layanan yang memudahkan bagi pelanggan, melainkan juga karena jasa transportasi online ride-sharing mampu membuka lapangan kerja baru bagi masyarakat yang membutuhkan (Wibawa, Rahmawati, \& Rainaldo, 2018).

Salah satu aplikasi ride sharing yang beroperasi di Indonesia adalah indriver, layanan ini baru beroperasi tahun ini di Indonesia (Fatihah, 2020). InDriver sendiri 
bukanlah perusahaan asli Indonesia, melainkan dari Rusia. InDriver bermula di kota Yakutsk, Siberia. Pada tahun 2012, cuaca yang dingin mencapai $-45^{\circ}$ membuat biaya tarif taksi menjadi mahal hingga dua kali lipat. Untuk mensiasati tarif yang tinggi tersebut, beberapa warga dan mahasiswa berinisiatif membuat grup pengemudi independen di jejaring sosial Vkontakte. Dalam enam bulan, grup tersebut telah diikuti sebanyak 60.000 orang dan terus berkembang denga pesat. Hingga akhirnya terbentuklah indriver yang saat ini telah hadir di lebih dari 450 kota di 32 negara.

\begin{tabular}{|c|c|c|c|c|c|}
\hline \multicolumn{2}{|c|}{ Overall Downloads } & \multicolumn{2}{|c|}{ App Store Downloads } & \multicolumn{2}{|c|}{ Google Play Downloads } \\
\hline 1 Uber & Uber & 1 & Uber & 1 Uber & Uber \\
\hline 2 Grob & Grab & $2 \circlearrowleft$ & $\mathrm{DiDi}$ & 2 arob & Grab \\
\hline $3 \sigma$ & $\mathrm{DiDi}$ & 3 arob & Grab & 30 & Ola \\
\hline 40 & Ola & 48 & Hello Travel & 499 & 99 \\
\hline 599 & 99 & 5 ty & Lyft & 5 i) & inDriver \\
\hline 6 i) & inDriver & 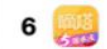 & Dida & $6 \sigma$ & DiDi \\
\hline 7 Bolt & Bolt & 7 Bolt & Bolt & 7 Q & Gojek \\
\hline 8 tya & Lyft & 80 & Yandex & 80 & Yandex \\
\hline 9 & Yandex & 96 & BlaBlaCar & 96 & BlaBlaCar \\
\hline $10 \bigcirc$ & Gojek & $10 \mathrm{C}$ & Cao Cao & 10 Boplt & Bolt \\
\hline
\end{tabular}

(1) Sensortower Data That Drives App Growth

sensortower.com

Sumber: https://kumparan.com/karjaid/mengenal-indriver-pesaing-baru-gojek- and-grab1sCtgTXz3Nn/ full, diakses 27 Desember 2020

\section{Gambar 1}

InDriver: 10 Besar Aplikasi Ridesharing

Berdasarkan gambar di atas menunjukkan bahwa sistem aplikasi InDriver memperoleh penerimaan yang luas di dunia. Mengingat sistem aplikasi InDriver relatif baru di Indonesia, maka perlu dilakukan analisis dan pengujian terkait dengan penerimaan sistem aplikasi tersebut oleh penggunanya. Dimensi apa saja yang menjadi keunggulan sistem aplikasi InDriver dibandingkan dengan pendahulunya seperti Uber, Grab dan Gojek yang juga menawarkan jasa transportasi ride sharing berbasis online. Salah satu fitur yang menonjol yang ditawarkan oleh InDriver adalah fleksibilitas harga, dimana konsumen adalah penentu akhir layanan yang dipilih.

Sebuah sistem aplikasi yang akan diimplementasikan dan digunakan oleh pengguna akhir (user) perlu diuji terkait dengan apakah sistem tersebut secara efektif dan efisien dapat diterima oleh penggunanya (Budiman \& Arza, 2013). Pengujian penerimaan (acceptance) terhadap sebuah teknologi informasi atau sistem dapat menggunakan beberapa macam teori ditinjau dari sudut pandang yang berbeda. Terdapat beberapa teori dan model telah diajukan selama bertahun-tahun untuk menjelaskan perilaku penggunaan individu terhadap teknologi (Momani \& Jamous, 2017). Dalam tiga dekade tarkhir, teori yang paling mempengaruhi para peneliti sistem 
informasi adalah Theory of Acceptance Model (TAM1) yang dikembangkan oleh (Davis, 1989); TAM2 yang diperbaharui oleh (Venkatesh \& Davis, 2000); Modified TAM oleh (Venkatesh, Morris, Davis, \& Davis, 2003), (Ilmi, Liyundira, Rachmawati, Juliasari, \& Habsari, 2020).

Technology Acceptance Model (TAM) bertujuan untuk menjelaskan dan memperkirakan penerimaan (acceptance) pengguna dan faktor-faktor yang mempengaruhi penerimaan terhadap suatu teknologi dalam suatu organisasi. TAM juga menjelaskan hubungan sebab akibat antara keyakinan dan perilaku, tujuan atau keperluan, serta penggunaan aktual dari pengguna suatu sistem informasi. Pendapat dari (Davis, 1989) memberikan penjelasan mengenai dua konsep utama yang dipercaya dalam penerimaan pengguna yaitu persepsi kemudaham (perceived ease of use) dan persepsi kegunaan (perceived usefulness). Perceived ease of use didefinisikan sebagai tingkat kepercayaan seseorang bahwa, penggunaan teknologi dan sistem informasi akan mudah dan tidak membutuhkan usaha yang keras. Perceived usefulness didefinisikan sebagai tingkat kepercayaan seseorang bahwa, penggunaan sistem informasi meningkatkan kinerja dalam pekerjaannya. Dalam model TAM, terdapat dua faktor yang dipertimbangkan yaitu kegunaan (usefulness) dan kemudahan penggunaan (ease of use) yang dianggap relevan dalam perilaku penggunaan komputer. Pendapat dari (Davis, 1989) mendefinisikan mengenai kegunaan yang dirasakan sebagai kemungkinan subjektif calon pengguna bahwa menggunakan sistem aplikasi tertentu akan meningkatkan pekerjaan atau kinerja hidupnya. Kemudahan penggunaan EOU (Eastern Oregon University) dapat didefinisikan sebagai sejauh mana calon pengguna mengharapkan sistem target bebas dari usaha. Menurut TAM, kemudahan penggunaan dan kegunaan yang dirasakan adalah determinan terpenting dari penggunaan sistem yang sebenarnya. Kedua faktor tersebut dipengaruhi oleh variabel eksternal.

Beberapa fitur unggulan inDriver dibandingkan kompetitor antara lain: aplikasi inDriver hanya membutuhkan satu aplikasi saja bagi para penggunanya. Aplikasi inDriver dapat digunakan bagi mitra pengemudi maupun penumpang. Pengemudi tidak perlu menginstal aplikasi khusus untuk para pengemudi. InDriver tidak melayani layanan antar menggunakan motor, melainkan hanya untuk mobil saja. Untuk saat ini, inDriver pun tidak memberikan pelayanan pengantaran barang ataupun pembelian makanan seperti Gojek maupun Grab. Fleksibilitas harga, layanan inilah yang menjadi keunggulan InDriver. Penumpang dapat memasang penawaran tarif antar untuk tujuan yang dituju. Kemudian, beberapa pilihan pengemudi dengan kisaran tarif yang sesuai akan muncul. Barulah penumpang akan memilih pengemudi yang akan mengantar. Beberapa fitur inilah yang dipertimbangkan untuk dianalisis dalam konteks penerimaan (acceptance) sistem aplikasi dengan pendekatan Modified Technology Acceptance Model (M-TAM). Penelitian ini perlunya dilakukan supaya mampu mengukur hasil dari penggunaan aplikasi InDriver dengan menggunakan pendekatan modified technology acceptance model.

Penelitian terdahulu mengenai online ride-sharing pada aplikasi InDriver sama halnya dengan penelitian yang dilakukan oleh (Wibawa et al., 2018) mengenai industri 
online-ride sharing di Indonesia cukup menarik untuk dikembangkan di masa depan karena jumlah pelanggan yang belum mencapai titik maksimal, terlebih industri ini dapat menawarkan diferensiasi produk yang sangat bervariasi.

Berdasarkan fenomena dan latar belakang di atas, tujuan dari penelitian ini adalah menguji apakah fleksibilitas harga (price flexibility), kualitas layanan (service quality), persepsi kemudahan (perceived ease of use) dan persepsi kegunaan (perceived usefulness) berpengaruh terhadap kepuasan pengguna (customers satisfaction) dan niat untuk menggunakan (behavioral intention to use) sistem aplikasi Indriver.

\section{Metode Penelitian}

Data penelitian ini diperoleh dari 100 responden pengguna aplikasi inDriver di wilayah Jakarta Selatan. Metode penentuan sampel dengan menggunakan quota sampling untuk memenuhi kecukupan data dalam analisis. Kuisioner dibagikan secara daring (online) kepada pengguna sistem aplikasi indriver di Jakarta Selatan. Pengukuran indikator untuk seluruh konstruks menggunakan 5 points Likert Scale. Indikator dan konstruk yang digunakan dalam penelitian dapat dilihat pada Tabel 1.

\section{Tabel 1}

\section{Konstruk,Indikator dan Acuan}

\begin{tabular}{|c|c|c|}
\hline Konstruk & Indikator & Sumber \\
\hline $\begin{array}{l}\text { Fleksibilitas } \\
\text { Harga }\end{array}$ & $\begin{array}{l}\text { 1. Harga berdasarkan kesepakatan pengguna } \\
\text { dan driver } \\
\text { 2. Harga termurah dibandingkan pesaing } \\
\text { 3. Pengguna sebagai penentu akhir harga } \\
\text { yang dipilih }\end{array}$ & Fitur utama inDriver \\
\hline $\begin{array}{l}\text { Persepsi } \\
\text { Kemudahan }\end{array}$ & $\begin{array}{ll}\text { 1. } & \text { Mudah dipelajari } \\
\text { 2. } & \text { Mempermudah penggunaan } \\
\text { 3. } & \text { Meningkatkan keterampilan } \\
\text { 4. } & \text { Mudah dioperasikan } \\
\end{array}$ & $\begin{array}{l}\text { (Davis, 1989); } \\
\text { (Venkatesh \& Davis, } \\
\text { 2000); (Venkatesh et } \\
\text { al., 2003) }\end{array}$ \\
\hline $\begin{array}{l}\text { Persepsi } \\
\text { Kegunaan }\end{array}$ & $\begin{array}{ll}\text { 1. } & \text { Bermanfaat } \\
\text { 2. } & \text { Efisien } \\
\text { 3. } & \text { Masa tunggu sebentar } \\
\text { 4. } & \text { Efektif } \\
\end{array}$ & $\begin{array}{l}\text { (Davis, 1989); } \\
\text { (Venkatesh \& Davis, } \\
\text { 2000); (Venkatesh et } \\
\text { al., 2003) }\end{array}$ \\
\hline $\begin{array}{l}\text { Kualitas } \\
\text { Layanan }\end{array}$ & $\begin{array}{ll}\text { 1. } & \text { Bukti Fisik (Tangible) } \\
\text { 2. } & \text { Keandalan (Reliability) } \\
\text { 3. } & \text { Ketanggapan (Responsiveness) } \\
\text { 4. } & \text { Jaminan Kepastian (Assurance) } \\
\text { 5. } & \text { Empathy (Empati) } \\
\end{array}$ & $\begin{array}{l}\text { Service Quality } \\
\text { (Parasuraman, 1998) }\end{array}$ \\
\hline $\begin{array}{l}\text { Kepuasan } \\
\text { Pengguna }\end{array}$ & $\begin{array}{ll}\text { 1. } & \text { Kecepatan mendapatkan pengemudi } \\
\text { 2. } & \text { Harga atau biaya yang wajar } \\
\text { 3. } & \text { Sopan santun pengemudi } \\
\text { 4. } & \text { Kemdahan penggunaan aplikasi }\end{array}$ & $\begin{array}{l}\text { Kepuasan Pelanggan } \\
\text { (Ciptono, 2014) }\end{array}$ \\
\hline $\begin{array}{l}\text { Niat } \\
\text { Perilaku }\end{array}$ & $\begin{array}{ll}\text { 1. } & \text { Minat Transaksional } \\
\text { 2. } & \text { Minat Referensial }\end{array}$ & $\begin{array}{l}\text { Niat pembelian ulang } \\
\text { (Mahardika 2017) }\end{array}$ \\
\hline
\end{tabular}




\begin{tabular}{lll}
\hline Konstruk & \multicolumn{1}{c}{ Indikator } & Sumber \\
\hline Pengguna & 3. Minat Preferensial & \\
\cline { 2 - 3 } & 4. Minat Exploratif & \\
\cline { 2 - 3 } 5. Minat berkaitan Kualitas & \\
\hline
\end{tabular}

\section{Hasil dan Pembahasan}

\section{Deskripsi Responden}

Berdasarkan data yang diperoleh dan hasil analsisis statistik deskriptif, dibawah ini disajikan karakteristik responden berdasarkan jenis kelamin, kelompok usia dan jenjang pendidikan. Hasil selengkapnya dapat dilihat pada tabel-tabel di bawah ini:

Tabel 1

Karakteristik Responden Berdasarkan Jenis Kelamin, Kelompok Usia dan Jenjang Pendidikan

\begin{tabular}{|c|c|c|c|c|c|}
\hline & & Frequency & Percent & $\begin{array}{c}\text { Valid } \\
\text { Percent }\end{array}$ & $\begin{array}{c}\text { Cumulative } \\
\text { Percent } \\
(\%)\end{array}$ \\
\hline \multirow[t]{3}{*}{ Valid } & Laki-laki & 56 & 56.0 & 56.0 & 56.0 \\
\hline & Perempuan & 44 & 44.0 & 44.0 & 100.0 \\
\hline & Total & 100 & 100.00 & 100.0 & \\
\hline \multicolumn{6}{|c|}{ Kelompok Usia } \\
\hline \multirow[t]{5}{*}{ Valid } & $<20$ Tahun & 19 & 19.0 & 19.0 & 19.0 \\
\hline & $\begin{array}{l}21-30 \\
\text { Tahun }\end{array}$ & 43 & 43.0 & 43.0 & 62.0 \\
\hline & $\begin{array}{l}31-40 \\
\text { Tahun }\end{array}$ & 26 & 26.0 & 26.0 & 88.0 \\
\hline & $>40$ Tahun & 18 & 12.0 & 12.0 & 100.0 \\
\hline & Total & 100 & 100.0 & 100.0 & \\
\hline \multicolumn{6}{|c|}{ Jenjang Pendidikan } \\
\hline \multirow[t]{5}{*}{ Valid } & $\begin{array}{l}\text { SMA } \\
\text { Sederajat }\end{array}$ & 20 & 20.0 & 20.0 & 20.0 \\
\hline & Diploma & 32 & 32.0 & 32.0 & 52.0 \\
\hline & S1 & 40 & 40.0 & 40.0 & 92.0 \\
\hline & Pascasarjana & 8 & 8.0 & 8.0 & 100.0 \\
\hline & Total & 100 & 100.0 & 100.0 & \\
\hline
\end{tabular}

\section{Pengujian Model Struktural}

Pengujian model struktural dilakukan dengan menggunakan Structural Equation Model-Partial Least Squares (SEM-PLS). Dalam penelitian ini, seluruh hipotesis yang diajukan dalam penelitian diuji secara simultan. Hasil uji SEM-PLS terhadap model struktural analisis penerimaan sistem aplikasi inDriver: Pendekatan Modified Technology Acceptance Model dapat dilihat pada Gambar 4 di bawah ini. 


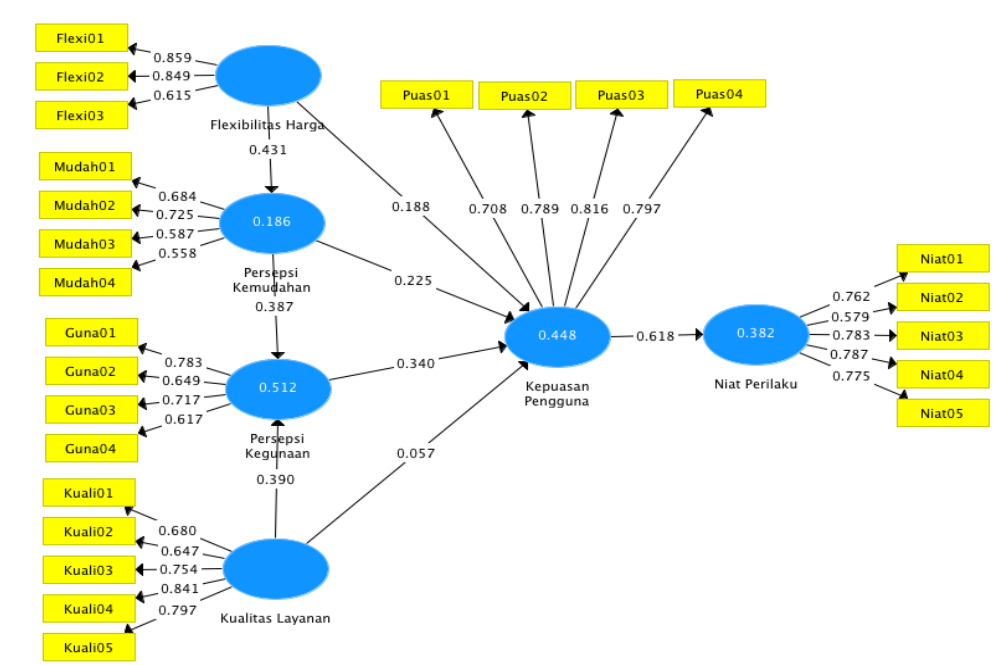

Gambar 2

Model Struktural Analisis Penerimaan Sistem Aplikasi indriver

Untuk penelitian exploratory, suatu indikator dinyatakan valid jika mempunyai loading faktor di atas 0,5 terhadap konstruk yang dituju. Outer loading untuk masing-masing indikator dalam setiap konstruk dapat dilihat pada tabel di bawah ini.

Tabel 2

Outer Loading Factor Konstruks Penelitian

\begin{tabular}{|c|c|c|c|c|c|c|}
\hline & $\begin{array}{c}\text { Fleksibilitas } \\
\text { Harga }\end{array}$ & $\begin{array}{c}\text { Persepsi } \\
\text { Kemudahan }\end{array}$ & $\begin{array}{c}\text { Persepsi } \\
\text { Kegunaan }\end{array}$ & $\begin{array}{l}\text { Kualitas } \\
\text { Layanan }\end{array}$ & $\begin{array}{l}\text { Kepuasan } \\
\text { Pengguna }\end{array}$ & $\begin{array}{c}\text { Niat } \\
\text { Perilaku }\end{array}$ \\
\hline Flexi01 & 0.859 & & & & & \\
\hline Flexi02 & 0.849 & & & & & \\
\hline Flexi03 & 0.615 & & & & & \\
\hline Mudah01 & & 0.684 & & & & \\
\hline Mudah02 & & 0.725 & & & & \\
\hline Mudah03 & & 0.587 & & & & \\
\hline Mudah04 & & 0.558 & & & & \\
\hline Guna01 & & & 0.783 & & & \\
\hline Guna02 & & & 0.649 & & & \\
\hline Guna03 & & & 0.717 & & & \\
\hline Guna04 & & & 0.617 & & & \\
\hline Kuali01 & & & & 0.680 & & \\
\hline Kuali02 & & & & 0.647 & & \\
\hline Kuali03 & & & & 0.754 & & \\
\hline Kuali04 & & & & 0.841 & & \\
\hline Kuali05 & & & & 0.797 & & \\
\hline Puas01 & & & & & 0.708 & \\
\hline Puas02 & & & & & 0.789 & \\
\hline Puas03 & & & & & 0.816 & \\
\hline Puas04 & & & & & 0.797 & \\
\hline Niat01 & & & & & & 0.762 \\
\hline Niat02 & & & & & & 0.579 \\
\hline
\end{tabular}




\begin{tabular}{lcccccc}
\hline & $\begin{array}{c}\text { Fleksibilitas } \\
\text { Harga }\end{array}$ & $\begin{array}{c}\text { Persepsi } \\
\text { Kemudahan }\end{array}$ & $\begin{array}{c}\text { Persepsi } \\
\text { Kegunaan }\end{array}$ & $\begin{array}{c}\text { Kualitas } \\
\text { Layanan }\end{array}$ & $\begin{array}{c}\text { Kepuasan } \\
\text { Pengguna }\end{array}$ & $\begin{array}{c}\text { Niat } \\
\text { Perilaku }\end{array}$ \\
\hline Niat03 & & & & & & 0.783 \\
\hline Niat04 & & & & & 0.787 \\
\hline Niat05 & & & & & 0.775 \\
\hline
\end{tabular}

Sumber: Data Penelitian 2021; Diolah dengan SPSS 25.0

Berdasarkan tabel di atas, nilai loading factor untuk setiap indikator dalam konstruks penelitian yang disarankan adalah diatas 0.7 , untuk penelitian ekplanatory, dan 0.6 untuk penelitian eksploratory. Berdasarkan hasil analisis di atas model structural perlu dimodifikasi.

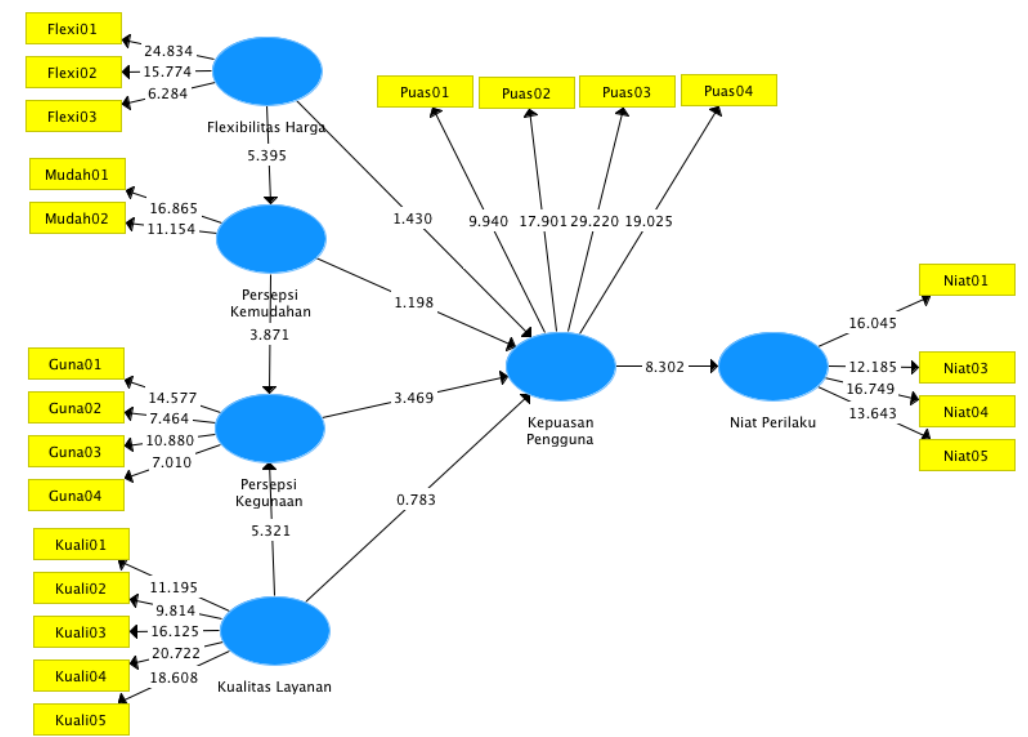

Gambar 3

T Statistik Model Struktural Analisis Penerimaan Sistem Aplikasi in Driver setelah Modifikasi

Uji reliabilitas dilakukan dengan melihat nilai composite reliability dari blok indikator yang mengukur konstruk. Untuk keperluan confirmatory, model dianggap reliable dan memuaskan jika nilai composite reliability di atas 0,7. Uji reliabilitas juga bisa diperkuat dengan Cronbach's Alpha dengan nilai yang disarankan adalah di atas 0,6. Metode lain untuk melihat validitas konvergen (discriminant validity) adalah juga ditunjukkan dengan melihat nilai Square Root of Average Variance Extracted (AVE). Nilai yang disarankan adalah di atas 0,5.

Setelah model yang diestimasi memenuhi kriteria Outer Model, berikutnya dilakukan pengujian model structural (inner model). dapat dilihat dalam Tabel 2. 
Tabel 3

Reliability \& Average Variance Extracted

\begin{tabular}{lccc}
\hline \multicolumn{1}{c}{ Konstruks } & Cronbach's Alpha & $\begin{array}{c}\text { Composite } \\
\text { Reliability }\end{array}$ & $\begin{array}{c}\text { Average Variance } \\
\text { Extracted }(\boldsymbol{A V E})\end{array}$ \\
\hline Fleksibilitas Harga & 0.820 & 0.917 & 0.847 \\
\hline $\begin{array}{l}\text { Persepsi } \\
\text { Kemudahan }\end{array}$ & 0.414 & 0.770 & 0.628 \\
\hline Persepsi Kegunaan & 0.566 & 0.820 & 0.695 \\
\hline Kualitas Layanan & 0.798 & 0.875 & 0.613 \\
\hline $\begin{array}{l}\text { Kepuasan } \\
\text { Pengguna }\end{array}$ & 0.785 & 0.860 & 0.607 \\
\hline $\begin{array}{l}\text { Niat Perilaku } \\
\text { Pengguna }\end{array}$ & 0.792 & 0.865 & 0.615 \\
\hline
\end{tabular}

Sumber: Data Penelitian 2021; Diolah dengan SPSS 25.0

Besaran loading factor pengaruh satu konstruk terhadap konstruk lainnya tercermin dari original sampel. Semakin besar nilai loading factor menunjukkan semakin besar pula pengaruh satu konstruk terhadap konstruk lainnya. Signifikansi hubungan antar konstruk tercermin dari nilai $t_{\text {statistic }}$ atau thitung dapat dilihat dalam tabel 3 di bawah ini.

Tabel 4

Inner Loading Factor Hubungan Antar Konstruks

\begin{tabular}{|c|c|c|c|c|c|c|}
\hline & & $\begin{array}{l}\text { Original } \\
\text { Sample } \\
(\mathbf{O})\end{array}$ & $\begin{array}{c}\text { Sample } \\
\text { Mean } \\
\text { (M) }\end{array}$ & $\begin{array}{l}\text { Standard } \\
\text { Deviation }\end{array}$ & $\begin{array}{c}\mathbf{T} \\
\text { Statistic }\end{array}$ & $\begin{array}{c}\mathbf{P} \\
\text { Values }\end{array}$ \\
\hline $\begin{array}{l}\text { Fleksibilitas } \\
\text { Harga }\end{array}$ & $\begin{array}{ll}- & \text { Persepsi } \\
> & \text { Kemudahan }\end{array}$ & 0.457 & 0.463 & 0.081 & 5.637 & 0.000 \\
\hline $\begin{array}{l}\text { Fleksibilitas } \\
\text { Harga }\end{array}$ & $\begin{array}{ll}- & \text { Kepuasan } \\
> & \text { Pengguna } \\
\end{array}$ & 0.113 & 0.114 & 0.121 & 0.936 & 0.350 \\
\hline $\begin{array}{l}\text { Persepsi } \\
\text { Kemudahan }\end{array}$ & $\begin{array}{ll}- & \text { Persepsi } \\
> & \text { Kegunaan } \\
\end{array}$ & 0.330 & 0.340 & 0.113 & 2.925 & 0.004 \\
\hline $\begin{array}{l}\text { Persepsi } \\
\text { Kemudahan }\end{array}$ & $\begin{array}{ll}\text { - } & \text { Kepuasan } \\
> & \text { Pengguna } \\
\end{array}$ & 0.274 & 0.281 & 0.130 & 2.116 & 0.035 \\
\hline $\begin{array}{l}\text { Kualitas } \\
\text { Layanan }\end{array}$ & $\begin{array}{ll} & \text { Persepsi } \\
> & \text { Kegunaan } \\
\end{array}$ & 0.384 & 0.376 & 0.113 & 3.387 & 0.001 \\
\hline $\begin{array}{l}\text { Kualitas } \\
\text { Layanan }\end{array}$ & $\begin{array}{ll}- & \text { Kepuasan } \\
> & \text { Pengguna } \\
\end{array}$ & 0.027 & 0.033 & 0.126 & 0.211 & 0.833 \\
\hline $\begin{array}{l}\text { Persepsi } \\
\text { Kegunaan }\end{array}$ & $\begin{array}{ll}\text { - } & \text { Kepuasan } \\
> & \text { Pengguna } \\
\end{array}$ & 0.331 & 0.318 & 0.103 & 3.211 & 0.001 \\
\hline $\begin{array}{l}\text { Kepuasan } \\
\text { Pengguna }\end{array}$ & $\begin{array}{ll}- & \text { Niat } \\
> & \text { Perilaku } \\
& \text { Pengguna }\end{array}$ & 0.625 & 0.631 & 0.075 & 8.345 & 0.000 \\
\hline
\end{tabular}

Sumber: Data Penelitian 2021; Diolah dengan SPSS 25.0 


\section{Pengujian Hipotesis}

Pengujian hipotesis dilakukan dengan membandingkan nilai $\mathrm{T}_{\text {Statistic }}$ dan nilai Probability $(p)$ dari perhitungan Full Model Structural. Batasan statistik yang disyaratkan untuk confidence interval $95 \%$ atau alpha $5 \%$ untuk masing nilai $\mathrm{T}_{\text {Statistic }}$ adalah dibawah -1.96 atau nilai $\mathrm{T}_{\text {Statistic }}$ di atas 1.96 dan nilai $\mathrm{p}$ dibawah 0.05 . Apabila hasil pengujian menunjukkan nilai yang memenuhi batasan tersebut, maka hipotesis yang diajukan diterima.

Berdasarkan hasil pengujian hipotesis sebagaimana dapat dilihat pada tabel 3 di atas, pengujian hipotesis dalam penelitian dapat dijelaskan sebagai berikut:

Hipotesis 1 menyatakan bahwa fleksibilitas harga berpengaruh positif dan signifikan terhadap persepsi kemudahan memiliki loading factor sebesar 0.457 dengan nilai thitung sebesar 5.637 dengan pvalue sebesar 0.000. Dengan demikian hipotesis 1 yang menyatakan bahwa fleksibilitas harga berpengaruh positif dan signifikan terhadap persepsi kemudahan secara statistik diterima.

Hipotesis 2 menyatakan bahwa fleksibilitas harga berpengaruh positif dan signifikan terhadap kepuasan pengguna memiliki loading factor sebesar 0.113 dengan nilai thitung sebesar 0.936 dengan $p_{\text {value }}$ sebesar 0.350 . Dengan demikian hipotesis 2 yang menyatakan bahwa fleksibilitas harga berpengaruh positif dan signifikan terhadap kepuasan pengguna secara statistik ditolak.

Hipotesis 3 menyatakan bahwa persepsi kemudahan berpengaruh positif dan signifikan terhadap persepsi kegunaan memiliki loading factor sebesar 0.330 dengan nilai thitung sebesar 2.925 dengan $p_{\text {value }}$ sebesar 0.004. Dengan demikian hipotesis 3 yang menyatakan bahwa persepsi kemudahan berpengaruh positif dan signifikan terhadap persepsi kegunaan secara statistik diterima.

Hipotesis 4 menyatakan bahwa persepsi kemudahan berpengaruh positif dan signifikan terhadap kepuasan pengguna memiliki loading factor sebesar 0.274 dengan nilai $t_{\text {hitung }}$ sebesar 2.116 dengan $p_{\text {value }}$ sebesar 0.035. Dengan demikian hipotesis 4 yang menyatakan bahwa persepsi kemudahan berpengaruh positif dan signifikan terhadap kepuasan pengguna secara statistik diterima.

Hipotesis 5 menyatakan bahwa kualitas layanan berpengaruh positif dan signifikan terhadap persepsi kegunaan memiliki loading factor sebesar 0.384 dengan nilai thitung sebesar 3.387 dengan $p_{\text {value }}$ sebesar 0.001 . Dengan demikian hipotesis 5 yang menyatakan bahwa kualitas layanan berpengaruh positif dan signifikan terhadap persepsi kegunaan secara statistik diterima.

Hipotesis 6 menyatakan bahwa kualitas layanan berpengaruh positif dan signifikan terhadap kepuasan pengguna memiliki loading factor sebesar 0.027 dengan nilai $t_{\text {hitung }}$ sebesar 0.211 dengan $p_{\text {value }}$ sebesar 0.833. Dengan demikian hipotesis 6 yang menyatakan bahwa kualitas layanan berpengaruh positif dan signifikan terhadap kepuasan pengguna secara statistik ditolak.

Hipotesis 7 menyatakan bahwa persepsi kegunaan berpengaruh positif dan signifikan terhadap kepuasan pengguna memiliki loading factor sebesar 0.331 dengan nilai $t_{\text {hitung }}$ sebesar 3.211 dengan $p_{\text {value }}$ sebesar 0.001. Dengan demikian 
hipotesis 7 yang menyatakan bahwa persepsi kegunaan berpengaruh positif dan signifikan terhadap kepuasan pengguna secara statistik diterima.

Hipotesis 8 menyatakan bahwa kepuasan pengguna berpengaruh positif dan signifikan terhadap niat perilaku pengguna memiliki loading factor sebesar 0.625 dengan nilai thitung sebesar 8.345 dengan $p_{\text {value }}$ sebesar 0.000. Dengan demikian hipotesis 8 yang menyatakan bahwa kepuasan pengguna berpengaruh positif dan signifikan terhadap niat perilaku pengguna secara statistik diterima.

Secara ringkas hasil pengujian dan pembuktian seluruh hipotesis yang diajukan dalam penelitian ini dapat dilihat pada tabel di bawah ini.

Tabel 5

Ringkasan Pengujian Hipotesis

\begin{tabular}{|c|c|c|c|c|c|c|c|c|c|}
\hline Hipotesis & & & & $\begin{array}{c}\text { Original } \\
\text { Sample } \\
(0)\end{array}$ & $\begin{array}{c}\text { Sample } \\
\text { Mean } \\
(\mathrm{M})\end{array}$ & $\begin{array}{c}\text { Standard } \\
\text { Deviatio } \\
n \\
\end{array}$ & $\begin{array}{c}T \\
\text { Statis } \\
\text { tic }\end{array}$ & $\begin{array}{c}\mathbf{P} \\
\text { Value } \\
\mathbf{S} \\
\end{array}$ & Ket \\
\hline 1 & $\begin{array}{l}\text { Fleksibilitas } \\
\text { Harga }\end{array}$ & $>$ & $\begin{array}{l}\text { Persepsi } \\
\text { Kemudaha } \\
\text { n }\end{array}$ & 0.457 & 0.463 & 0.081 & 5.637 & 0.000 & Diterima \\
\hline 2 & $\begin{array}{l}\text { Fleksibilitas } \\
\text { Harga }\end{array}$ & $>$ & $\begin{array}{l}\text { Kepuasan } \\
\text { Pengguna } \\
\end{array}$ & 0.113 & 0.114 & 0.121 & 0.936 & 0.350 & Ditolak \\
\hline 3 & $\begin{array}{l}\text { Persepi } \\
\text { Kemudahan }\end{array}$ & $>$ & $\begin{array}{l}\text { Persepsi } \\
\text { Kegunaan }\end{array}$ & 0.330 & 0.340 & 0.113 & 2.925 & 0.004 & Diterima \\
\hline 4 & $\begin{array}{l}\text { Persepis } \\
\text { Kemudahan }\end{array}$ & $>$ & $\begin{array}{l}\text { Kepuasan } \\
\text { Pengguna }\end{array}$ & 0.274 & 0.281 & 0.130 & 2.116 & 0.035 & Diterima \\
\hline 5 & $\begin{array}{l}\text { Kualitas } \\
\text { Layanan }\end{array}$ & $>$ & $\begin{array}{l}\text { Persepsi } \\
\text { Kegunaan }\end{array}$ & 0.384 & 0.376 & 0.113 & 3.387 & 0.001 & Diterima \\
\hline 6 & $\begin{array}{l}\text { Kualitas } \\
\text { Layanan }\end{array}$ & $>$ & $\begin{array}{l}\text { Kepuasan } \\
\text { Pengguna }\end{array}$ & 0.027 & 0.033 & 0.126 & 0.211 & 0.833 & Ditolak \\
\hline 7 & $\begin{array}{l}\text { Persepsi } \\
\text { Kegunaan }\end{array}$ & $>$ & $\begin{array}{l}\text { Kepuasan } \\
\text { Pengguna }\end{array}$ & 0.331 & 0.318 & 0.103 & 3.211 & 0.001 & Diterima \\
\hline 8 & $\begin{array}{l}\text { Kepuasan } \\
\text { Pengguna }\end{array}$ & $>$ & $\begin{array}{l}\text { Niat } \\
\text { Perilaku } \\
\text { Pengguna }\end{array}$ & 0.625 & 0.631 & 0.075 & 8.345 & 0.000 & Diterima \\
\hline
\end{tabular}

Fitur fleksibilitas harga sebagai fitur unggulan dari inDriver perlu terus dikembangkan dan dijadikan sebagai competitive advantage dibandingkan dengan pendahulunya seperti Gojek dan Grab. Sebagai pendatang baru inDriver dituntut untuk terus mengembangkan kualitas layanan sebagaimana diharapkan oleh pengguna atau customer. Dalam industri jasa, termasuk layanan transportasi, kualitas layanan merupakan faktor utama agar jasa yang diberikan dapat diterima dengan baik oleh pengguna. Hasil penelitian ini mengkonfirmasi beberapa penelitian terkait dengan layanan jasa transportasi ojek maupun taksi online (Agustin \& Khuzaini, 2017); (Pribadi \& Kusdibyo, 2019); (Rahman \& Dewantara, 2017); (Rahayu, 2018); (Diop, Zhao, \& Duy, 2019) bahwa sebagai pendatang baru di indonesia, inDriver sebenarnya telah beroperasi di wilayah metropolitan terbesar dengan tingkat persaingan tertinggi. Ini juga beroperasi di kota-kota kecil dengan populasi antara tujuh hingga delapan ribu penduduk (yang seringkali memiliki koneksi internet yang sangat lemah dan tidak ada peta). Oleh karena itu, inDriver terbukti berhasil 
beradaptasi dengan kebutuhan masyarakat. Saat ini, inDriver menjadi salah satu dari 5 layanan penumpang internasional teratas di seluruh dunia. inDriver secara aktif melakukan ekspansi internasional, memberikan kesempatan kepada banyak pengguna untuk menentukan persyaratan perjalanan yang optimal dan melindungi mereka dari manipulasi harga.

Terdapat tiga fitur utama yang merupakan value yang diberikan oleh layanan inDriver, sebagai berikut:

1. Term yang transparan, semua ketentuan perjalanan ditentukan selama transaksi instan antara pengemudi dan penumpang. Ini dilakukan tanpa menggunakan algoritme tertutup dan ambigu yang tunduk pada manipulasi harga.

2. Biaya selalu lebih rendah, biaya perjalanan dengan inDriver selalu lebih rendah. Ini karena model penawaran waktu nyata membantu inDrive menetapkan biaya optimal untuk penumpang dan pengemudi setiap detik.

3. Pembayaran langsung, penumpang membayar pengemudi secara langsung (dengan uang tunai atau dengan kartu). Hal ini memungkinkan inDriver untuk mengurangi biaya dan mempertahankan tarif yang lebih rendah dalam sistem.

Fleksibilitas harga yang merupakan fitur unggulan dari inDriver memiliki pengaruh positif dan signifikan terhadap persepsi kemudahan. Fleksibilitas harga berpengaruh positif tetapi tidak signifikan terhadap kepuasan pengguna. Fitur fleksibilitas harga sebagai fitur unggulan dari inDriver perlu terus dikembangkan dan dijadikan sebagai competitive advantage dibandingkan dengan pendahulunya seperti Gojek dan Grab.

Kualitas layanan inDriver memiliki pengaruh positif dan signifikan terhadap persepsi kegunaan sistem aplikasi ini. Kualitas layanan memiliki pengaruh positif tetapi tidak signifkan terhadap kepuasan pengguna. Sebagai pendatang baru inDriver dituntut untuk terus mengembangkan kualitas layanan sebagaimana diharapkan oleh pengguna atau customer. Dalam industri jasa, termasuk layanan transportasi, kualitas layanan merupakan faktor utama agar jasa yang diberikan dapat diterima dengan baik oleh pengguna. Kepuasan pengguna merupakan prediktor utama agar sistem aplikasi dapat diterima.

\section{Kesimpulan}

Berdasarkan hasil penelitian dan pembahasan di atas, dapat disimpulkan beberapa hal sebagai berikut: Hipotesis 1 yang menyatakan bahwa fleksibilitas harga berpengaruh positif dan signifikan terhadap persepsi kemudahan secara statistik diterima. 1) Hipotesis 2 yang menyatakan bahwa fleksibilitas harga berpengaruh positif dan signifikan terhadap kepuasan pengguna secara statistik ditolak. 2) Hipotesis 3 yang menyatakan bahwa persepsi kemudahan berpengaruh positif dan signifikan terhadap persepsi kegunaan secara statistik diterima. 3) Hipotesis 4 yang menyatakan bahwa persepsi kemudahan berpengaruh positif dan signifikan terhadap kepuasan pengguna secara statistik diterima. 4) Hipotesis 5 yang menyatakan bahwa kualitas layanan berpengaruh positif dan signifikan terhadap persepsi kegunaan secara statistik diterima. 
5) Hipotesis 6 yang menyatakan bahwa kualitas layanan berpengaruh positif dan signifikan terhadap kepuasan pengguna secara statistik ditolak. 6) Hipotesis 7 yang menyatakan bahwa persepsi kegunaan berpengaruh positif dan signifikan terhadap kepuasan pengguna secara statistik diterima. 7) Hipotesis 8 yang menyatakan bahwa kepuasan pengguna berpengaruh positif dan signifikan terhadap niat perilaku pengguna secara statistik diterima. Berdasarkan hasil penelitian dan pangujian hipotesis, penelitian ini memiliki beberapa keterbatasan sebagai berikut: a. Jumlah sampel yang digunakan dalam penelitian ini relatif kecil (100) responden. Untuk menguji penerimaan sebuah sistem atau aplikasi diperlukan lebih banyak data untuk mengkonfirmasi ulang hasil penelitian dengan menggunakan data atau model yang lebih beragam. Penelitian berikutnya disarankan dapat menggunakan lebih banyak sampel pengguna aplikasi inDriver dengan cakupan wilayah yang lebih luas dan tidak hanya terbatas di Jakarta Selatan. b. Model yang dikembangkan dalam penelitian ini merupakan Modified Technology Acceptance Model dengan hanya menambahkan 2 variabel fleksibilitas harga yang merupakan fitur unggulan aplikasi in Driver dan kualitas layanan mengingat aplikasi ini berkaitan dengan layanan ride-sharing. Penelitian berikutnya diharapkan dapat lebih mengeksplorasi model TAM, misalnya dengan menggunakan TAM3 atau model lain yang dirancang khusus terkait dengan penerimaan teknologi pada perusahaan jasa khususnya terkait dengan jasa transportasi. 


\section{BIBLIOGRAFI}

Agustin, Anis, \& Khuzaini, Khuzaini. (2017). Persepsi Masyarakat Terhadap Penggunaan Transportasi Online (GO-JEK) Di Surabaya. Jurnal Ilmu dan Riset Manajemen (JIRM), 6(9).Google Scholar

Budiman, Fuad, \& Arza, Fefri Indra. (2013). Pendekatan Technology Acceptance Model dalam Kesuksesan Implementasi Sistem Informasi Manajamen Daerah. Wahana Riset Akuntansi, 1(1), 87-110.Google Scholar

Davis, Fred D. (1989). Perceived usefulness, perceived ease of use, and user acceptance of information technology. MIS Quarterly, 319-340.Google Scholar

Diop, El Bachir, Zhao, Shengchuan, \& Duy, Tran Van. (2019). An extension of the technology acceptance model for understanding travelers' adoption of variable message signs. PLoS One, 14(4), e0216007.Google Scholar

Dong, Yongqi, Wang, Shuofeng, Li, Li, \& Zhang, Zuo. (2018). An empirical study on travel patterns of internet based ride-sharing. Transportation Research Part C: Emerging Technologies, 86, 1-22.Google Scholar

Fatihah, Aprilia Nurul. (2020). TA: Analisis Penerimaan Pengguna Aplikasi Transportasi Online GoRide dan Grabike Menggunakan Metode UTAUT di Kota Surabaya. Universitas Dinamika.Google Scholar

Flores, Onesimo, \& Rayle, Lisa. (2017). How cities use regulation for innovation: the case of Uber, Lyft and Sidecar in San Francisco. Transportation Research Procedia, 25, 3756-3768. Google Scholar

Hastuti, Puji, Nurofik, Agus, Purnomo, Agung, Hasibuan, Abdurrozzaq, Aribowo, Handy, Faried, Annisa Ilmi, Tasnim, Tasnim, Sudarso, Andriasan, Soetijono, Irwan Kurniawan, \& Saputra, Didin Hadi. (2020). Kewirausahaan dan UMKM. Yayasan Kita Menulis.Google Scholar

Ilmi, Mainatul, Liyundira, Fetri Setyo, Rachmawati, Afria, Juliasari, Deni, \& Habsari, Palupi. (2020). Perkembangan Dan Penerapan Theory Of Acceptance Model (TAM) Di Indonesia. Relasi: Jurnal Ekonomi, 16(2), 436-458. Google Scholar

Magfiroh, Laila. (2019). Prospek bisnis transportasi online dalam masyarakat industrial: pendekatan islamic innovation disruptif. IAIN Palangka Raya.Google Scholar

Momani, Alaa M., \& Jamous, Mamoun. (2017). The evolution of technology acceptance theories. International Journal of Contemporary Computer Research (IJCCR), 1(1), 51-58.

Parasuraman, Anantharanthan. (1998). Customer service in business-to-business 
Bonny Hendrawan, Tomi Hartanto dan Sendy Wulansari

markets: an agenda for research. Journal of Business \& Industrial Marketing.Google Scholar

Pribadi, Rana Maulana, \& Kusdibyo, Lusianus. (2019). Analisis Pengaruh Kemudahan Penggunaan dan Kegunaan Penggunaan terhadap Sikap Penggunaan: Studi Kasus Pada Grab. Prosiding Industrial Research Workshop and National Seminar, 10(1), 629-636. Google Scholar

Rahayu, Rurie Wiedya. (2018). Pengaruh Persepsi Manfaat, Persepsi Kemudahan, Persepsi Risko, dan Inovasi Teknologi Terhadap Aplikasi Go Pay Dari PT. Gojek Indonesia.Google Scholar

Rahman, Abdul, \& Dewantara, Rizki Yudhi. (2017). Pengaruh Kemudahan Penggunaan dan Kemanfaatan Teknologi Informasi terhadap Minat Menggunakan Situs Jual Beli Online”(Studi Kasus pada Pengguna Situs Jual Beli “Z”). Jurnal Administrasi Bisnis, 52(1), 1-7.Google Scholar

Venkatesh, Viswanath, \& Davis, Fred D. (2000). A theoretical extension of the technology acceptance model: Four longitudinal field studies. Management Science, 46(2), 186-204.Google Scholar

Venkatesh, Viswanath, Morris, Michael G., Davis, Gordon B., \& Davis, Fred D. (2003). User acceptance of information technology: Toward a unified view. MIS Quarterly, 425-478.Google Scholar

Wibawa, Berto Mulia, Rahmawati, Yani, \& Rainaldo, Mathias. (2018). Analisis Industri Bisnis Jasa Online Ride Sharing di Indonesia. Esensi: Jurnal Bisnis Dan Manajemen, 8(1), 9-20.Google Scholar

\section{Copyright holder :}

Bonny Hendrawan, Tomi Hartanto dan Sendy Wulansari (2021)

First publication right :

Journal Syntax Idea

This article is licensed under:

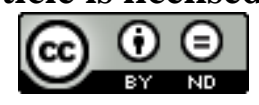

